\title{
Evaluation of the Antioxidant Potency of Seseli L. Species (Apiaceae)
}

\section{Seseli L. Türlerinin (Apiaceae) Antioksidan Potansiyellerinin Değerlendirilmesi}

\author{
(D) Alev ÖNDER ${ }^{1 *}$, (D) Ahsen Sevde ÇINAR 1,2 , (D) Sezen YILMAZ SARIALTIN33, (D) Mehmet Necat izGi4, (D) Tülay ÇOBAN3 \\ 1Ankara University Faculty of Pharmacy, Department of Pharmacognosy, Ankara, Turkey \\ 2Lokman Hekim University Faculty of Pharmacy, Department of Pharmacognosy/Pharmaceutical Botany, Ankara, Turkey \\ ${ }^{3}$ Ankara University Faculty of Pharmacy, Department of Pharmaceutical Toxicology, Ankara, Turkey \\ ${ }^{4}$ Mardin Artuklu University, Kızltepe Vocational Higher School, Mardin, Turkey
}

\section{ABSTRACT}

Objectives: In the present study, the antioxidant potency of ethyl acetate (AcOEt) and methanol (MeOH) extracts from the aerial parts of Seseli $\mathrm{L}$. species was investigated for the first time.

Materials and Methods: Seseli species L. such as Seseli andronakii Woronow ex Schischk., S. campestre Besser, S. corymbosum Boiss. \& Heldr., S. gummiferum subsp. gummiferum Pall. ex Sm., S. hartvigii Parolly \& Nordt, S. libanotis (L.) W.Koch, S. petraeum M.Bieb., S. peucedanoides (M.Bieb.) Koso-Pol., S. resinosum Freyn \& Sint., and S. tortuosum L. growing in Turkey were collected and evaluated for their antioxidant capacity by using 1.1-diphenyl-2-picrylhydrazyl (DPPH) radical scavenging and lipid peroxidation (LPO) inhibition methods.

Results: The highest activities as a scavenger of DPPH radicals were found in the AcOEt extracts of S. peucedanoides (M.Bieb.) Koso-Pol (IC ${ }_{50}=0.49$ $\mathrm{mg} / \mathrm{mL})$, and $S$. libanotis $\left(\mathrm{IC}_{50}=0.75 \mathrm{mg} / \mathrm{mL}\right) ; \alpha$-tocopherol was used as a positive control. On the other hand, in the LPO assay, the highest activities were determined in AcOEt and $\mathrm{MeOH}$ extracts (at $5 \mathrm{mg} / \mathrm{mL}$ ) of S. tortuosum and S. libanotis (84-94\%).

Conclusion: This report gives important information about the antioxidant capacity of Seseli L. species. This research on antioxidant capacity proves that the use of some species used in Eastern Anatolia (in salads) is correct. With this screening study performed in Seseli L. species growing in Turkey, in the future, it is planned to isolate antioxidant compounds from the most active strains of Seseli $\mathrm{L}$.

Key words: Antioxidant, Apiaceae, DPPH, LPO, Seseli

öz

Amaç: Bu çalıșmada, ilk kez Seseli L. türlerinin toprak üstü kısımlarından elde edilen, etil asetat (AcOEt) ve metanol (MeOH) ekstrelerinin antioksidan potansiyelleri araştırılmıştır.

Gereç ve Yöntemler: Türkiye'de yetișen bazı Seseli L. türlerinin, Seseli andronakii Woronow ex Schischk., S. campestre Besser, S. corymbosum Boiss. \& Heldr., S. gummiferum subsp. gummiferum Pall. ex Sm., S. hartvigii Parolly \& Nordt, S. libanotis (L.) W.Koch, S. petraeum M.Bieb., S. peucedanoides (M.Bieb.) Koso-Pol., S. resinosum Freyn \& Sint., S. tortuosum L., antioksidan kapasiteleri 1,1-difenil-2-pikrilhidrazil (DPPH) radikali süpürme kapasitesi ve lipit peroksidasyonu (LPO) inhibisyon yöntemleri ile değerlendirilmiștir.

Bulgular: En yüksek radikal süpürücü etkinin S. peucedanoides (M.Bieb.) Koso-Pol. $\left(\mathrm{IC}_{50}=0,49 \mathrm{mg} / \mathrm{mL}\right.$ ) ve $\mathrm{S}$. libanotis $\left(I C_{50}=0,75 \mathrm{mg} / \mathrm{mL}\right.$ ) EtOAc ekstrelerinde olduğu bulunmuştur; $\alpha$-tokoferol pozitif kontrol olarak kullanılmıştır. Diğer yandan, LPO deneyinde, en yüksek aktivite S. tortuosum ve S. libanotis (\%84-94)'in EtOAc ve $\mathrm{MeOH}$ ( $5 \mathrm{mg} / \mathrm{mL}$ dozda) ekstrelerinde tespit edilmiştir.

Sonuç: Bu çalışmada, Seseli L. türlerinin antioksidan kapasitesi hakkında önemli bilgiler elde edilmiştir. Antioksidan kapasiteleri üzerine yapılan bu araștırma ile, bazı türlerin Doğu Anadolu'da gıda olarak (salatalarda) kullanımının doğruluğu bir kez daha gösterilmiştir. Türkiyede yetişen Seseli L. türlerinde yapılan bu tarama çalışması ile, gelecekte, antioksidan etki gösteren bileșiklerin en aktif Seseli L. türlerinden izole edilmesi planlanmaktadır.

Anahtar kelimeler: Antioksidan, Apiaceae, DPPH, LPO, Seseli

*Correspondence: E-mail: pharmacogalev@gmail.com, Phone: +90 5303270735 ORCID-ID: orcid.org/0000-0002-9088-1045

Received: 11.10.2018, Accepted: 24.01.2019

-Turk J Pharm Sci, Published by Galenos Publishing House. 


\section{INTRODUCTION}

The Apiaceae (previously Umbelliferae) is a well-known family in the plant kingdom with aromatic plants and economically important species.' Some members of the family are used as foods, spices, condiments, and ornaments. ${ }^{2-4}$ The genus Seseli L. belongs to the family Apiaceae and is distributed in Asia and Europe, comprising more than 12 taxa in Turkey, of which 4 are native to the region. ${ }^{5-8}$ In addition, new species have recently been discovered. ${ }^{9-12}$ Moreover, the latest taxonomy of the type section of the genus Seseli has been given based on the molecular data with recently updated names. ${ }^{13}$ Seseli is an ancient Greek name given to some individual members of the family Apiaceae by Hippocrates. ${ }^{14}$ Seseli species are mainly rich in coumarins as well as terpenoids, essential oils, etc.15,16 and have many important pharmacological activities with healing effects such as in inflammation, swelling, rheumatism, pain, and the common cold. ${ }^{17}$ On the other hand, the fruit of $S$. indicum has been reported to have anthelmintic, carminative, stomachic, and stimulant properties. ${ }^{18} \mathrm{~S}$. sibiricum is used for blending beverages and as a medicine for livestock in Kashmir. ${ }^{19}$ In addition, the fruit of $S$. libanotis is a local remedy for blood pressure control in Pakistan, and its essential oil from the fruit has potent antimicrobial activity. ${ }^{20}$ While $S$. indicum exhibited strong insect repellent activity ${ }^{21}$ and fungitoxicity, ${ }^{22}$ the fruit of S. tortuosum is recorded to have emmenagogic and antiflatulent effects. ${ }^{23}$ Moreover, the leaves of S. libanotis (Kelemkeșir or Kelemenkeșir in Turkish) are consumed as a vegetable in salads in Eastern Turkey. ${ }^{24}$

In Turkey, there are limited studies on Seseli species based on coumarins ${ }^{25-29}$ and essential oils. ${ }^{30-34}$ Previously, antimicrobial, ${ }^{35}$ anti-inflammatory, and antinociceptive ${ }^{36-38}$ effects have been examined in Turkish Seseli species.

The plant kingdom presents secondary plant metabolites (especially polyphenols) as a wide range of natural antioxidants. ${ }^{39-42}$ The natural antioxidants in plants are of great interest in natural product science and many herbs have significant antioxidant potency. ${ }^{43}$ Antioxidants decrease oxidative stress in cells and are therefore very useful in the treatment of major degenerative diseases. ${ }^{44}$ The physiological role of antioxidant agents is to scavenge for free radicals ${ }^{45,46}$ in the case of overproduction of these reactive species. ${ }^{47}$

Therefore, in the present study, we aimed to investigate the antioxidant potential of the aerial parts of Turkish Seseli species. The species were screened using in vitro 1.1-diphenyl-2picrylhydrazyl (DPPH) radical scavenging and lipid peroxidation (LPO) inhibition assays.

\section{MATERIALS AND METHODS}

\section{Plant material}

Plant materials were collected from different localities in Turkey. All of the Seseli L. species were identified by Prof. H. Duman from the Department of Biology, Faculty of Science and Arts, Gazi University, Ankara, Turkey. Voucher specimens were deposited at the Herbarium of the Faculty of Pharmacy of Ankara University and the Herbarium of Gazi University, Ankara, Turkey. The species are listed in Table 1 (ethical committee approval and patient consent were not required).

\section{Extraction of the plants}

The extraction method in Fenglin et al..$^{48}$ and Báthori et al. ${ }^{49}$ was used with some modifications. The aerial parts of each plant material, which were dried and powdered, were prepared according to the procedures described below:

-The ethyl acetate (AcOEt) extract: The plant material $(10 \mathrm{~g})$ was extracted with AcOEt at room temperature by a magnetic stirrer (x200 mL) for 24 hour. The extract was evaporated to dryness in a vacuum to give a crude AcOEt extract.

-The methanol $(\mathrm{MeOH})$ extract: After the AcOEt extraction, the plant material $(10 \mathrm{~g})$ was extracted with $\mathrm{MeOH}(80 \%)$ at room temperature by a magnetic stirrer $(x 200 \mathrm{~mL})$ for 24 hour. The extract was evaporated to dryness in vacuo to give a crude methanolic extract. The yields of all extracts are given in Table 2.

Table 1. Plant names and collection sites of Turkish Seseli L. species

\begin{tabular}{llll} 
Species & Location & Herbarium no \\
\hline S. andronakii Woronow ex Schischk & Erzurum, Oltu-Sarıkayalar, 1450-1750 m & ED 1617 \\
\hline S. campestre Besser & İstanbul, Sultanbeyli, Paşaköy c. $500 \mathrm{~m}$ & ED 1656 \\
\hline S. corymbosum Boiss. and Heldr. & Antalya-Akseki, Pınarbaşı village 1650-1900 m & AEF 21701 \\
\hline S. gummiferum subsp. gummiferum Pall. ex Sm. & Ankara-Hasanoğlan, İdris mountain 1600-1700 m & AEF 21999 \\
\hline S. hartvigii Parolly and Nordt & Antalya-Saklıkent, Bakırlar mountain, 2300-2500 m & AEF 21700 \\
\hline S. libanotis (L.) W.Koch & Ardahan-Posof, 1900 m & ED 1622 \\
\hline S. petraeum M.Bieb. & Gümüşhane, The road to Alemdar village, 1400 m & ED 1644 \\
\hline S. peucedanoides (M.Bieb.) Koso-Polo & Ankara-Hasanoğlan, İdris mountain, 1600-1700 m & AEF 23158 \\
\hline S. resinosum Freyn and Sint. & Bartın-Çakraz, 0-5 m & AEF 21696 \\
\hline S. tortuosum L. & Ankara, Beynam forest, 1400 m & ED 1612 \\
\hline
\end{tabular}

AEF: Herbarium of the Faculty of Pharmacy of Ankara University 


\section{Chemicals}

Ascorbic acid, thiobarbituric acid (TBA), DPPH, and $\alpha$-tocopherol were purchased from Sigma Chemical Co (St. Louis, MO, USA).

\section{Antioxidant capacity of the extracts}

\section{Radical scavenging capacity (DPPH)}

The model of scavenging stable DPPH radicals is a widely used method to evaluate antioxidant activities in a relatively short time compared with other methods. The effect of antioxidants on DPPH radical scavenging is thought to be due to their hydrogen donating ability. ${ }^{50}$ The reaction mixture contained 100 $\mu \mathrm{M} \mathrm{DPPH}$ in $\mathrm{MeOH}$ and different concentrations of the crude extract. Absorbance at $517 \mathrm{~nm}$ was measured on a Shimadzu UV-1601 UV-VIS spectrometer at various concentrations (30 min after starting the reaction) at room temperature and the scavenging activity was calculated as the percentage of radical reduction. In our study, samples were dissolved in $\mathrm{MeOH}$ (80\%) and AcOEt to $10 \mathrm{mg} / \mathrm{mL}$ and diluted to various concentrations. The scavenging activity was calculated as the percentage of radical reduction. The values of $\mathrm{IC}_{50}$ were determined from a calibration curve for each plant extract. Each experiment was performed in triplicate. $I_{50}$ values were determined from a calibration curve for each plant extract and $\alpha$-tocopherol was used as the reference compound.

\section{Assay of lipid peroxidation (LPO)}

LPO was determined by a modified version of the method described by Mihara et al. ${ }^{51}$ It was measured spectrophotometrically by estimation of the TBA reactant substances (TBARS). Amounts of TBARS were expressed in nmoL malondialdehyde/g tissue. A typical optimized assay mixture containing $0.5 \mathrm{~mL}$ of liver homogenate, $0.1 \mathrm{~mL}$ of Tris- $\mathrm{HCl}$ buffer ( $\mathrm{pH} 7.2), 0.05 \mathrm{~mL}$ of 0.1 $\mathrm{mM}$ ascorbic acid, and $0.05 \mathrm{~mL}$ of $4 \mathrm{mM} \mathrm{FeCl}_{2}$ and $0.05 \mathrm{~mL}$ of various concentrations of crude extract or $\alpha$-tocopherol were incubated for $1 \mathrm{~h}$ at $37^{\circ} \mathrm{C}$. After incubation, $3.0 \mathrm{~mL}$ of $\mathrm{H}_{3} \mathrm{PO}_{4}$

Table 2. The yield of extracts from Turkish Seseli L. species

\begin{tabular}{lll} 
Species & $\begin{array}{l}\text { AcOEt extract } \\
(w / w \% ~ m g)\end{array}$ & $\begin{array}{l}\text { MeOH extract } \\
\text { (w/w \% m) }\end{array}$ \\
\hline SA & 370 & 154 \\
\hline SA & 390 & 154 \\
\hline SCa & 1030 & 108 \\
\hline SGG & 870 & 128 \\
\hline SH & 330 & 119 \\
\hline SL & 270 & 200 \\
\hline SP & 750 & 118 \\
\hline SPeu & 310 & 100 \\
\hline SR & 420 & 120 \\
\hline ST & 570 & 163
\end{tabular}

SA: S. andronakii, SH: S. hartvigii, ST: S. tortuosum, SL: S. libanotis, SGG: S.gummiferum subsp. gummiferum, SPeu: S. peucedanoides, SR: S. resinosum, SC: S. corymbosum, SCa: S. campestre, SP: S. petraeum, AcOEt: Ethyl acetate, MeOH: Methanol and $1 \mathrm{~mL}$ of $0.6 \%$ TBA were added and the resulting mixture was shaken vigorously. The mixture was boiled for 30 minute. After cooling, $n$-butanol was added and the mixture was shaken vigorously. Then the $n$-butanol phase was separated by centrifugation at $3000 \mathrm{rpm}$ for 10 minute. The absorbance of the supernatant was measured at $532 \mathrm{~nm}$ against a blank, which contained all reagents except the liver homogenate.

\section{Statistical analysis}

Values of experimental results were considered as the mean of at least three determinations ( \pm standard deviation).

\section{RESULTS AND DISCUSSION}

The present study deals with the radical scavenging activity (Table 3) and LPO (Table 4) of the AcOEt and MeOH extracts obtained from Seseli L. species growing in Turkey such as Seseli andronakii, S. campestre, S. corymbosum, S. gummiferum subsp. gummiferum, S. hartvigii, S. libanotis, S. petraeum, S. peucedanoides (M.Bieb.) Koso-Pol, S. resinosum, and $S$. tortuosum. The antioxidant activities of AcOEt and $\mathrm{MeOH}$ extracts obtained from the Seseli species were investigated by the DPPH scavenging and nonenzymatic rat hepatic microsomal LPO methods. In addition, their antioxidant activities were compared with those of the standard antioxidant $\alpha$-tocopherol. The DPPH free radical scavenger assay is a simple and basic screening method for the discovery of bioactive substances. Free radicals are species that damage all the components of the body (lipids, proteins, DNA, etc.) and take part in mutations. In this case, antioxidants are important for body protection, helping reduce oxidative damage in the human body, and prevent LPO in foods. ${ }^{52,53}$

\section{Table 3. Inhibitory effects of Seseli extracts on DPPH stable} radicals

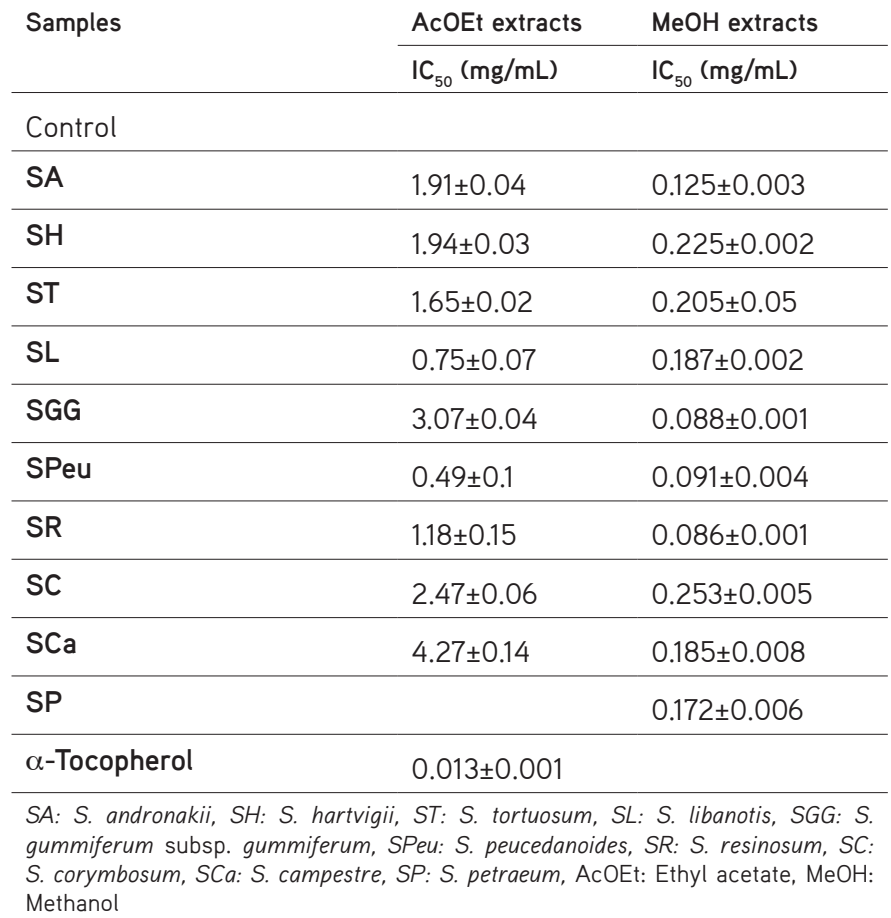


In our experiments, the results indicated that the extracts of some Turkish Seseli species have considerable effects on scavenging DPPH radicals (Figure 1). The AcOEt extract of $S$. peucedanoides $\left(\mathrm{IC}_{50}=0.49\right.$ $\mathrm{mg} / \mathrm{mL})$ and $S$. libanotis $\left(\mathrm{IC}_{50}=0.75 \mathrm{mg} / \mathrm{mL}\right)$ showed the most potent radical scavenging capacity (Table 3 ). These extracts were followed by $S$. resinosum $\left(\mathrm{IC}_{50}=1.18 \mathrm{mg} / \mathrm{mL}\right)$, S. tortuosum $\left(\mathrm{IC}_{50}=1.65 \mathrm{mg} / \mathrm{mL}\right)$, S. andronakii $\left(\mathrm{IC}_{50}=1.91 \mathrm{mg} / \mathrm{mL}\right), S$. hartvigii $\left(\mathrm{IC}_{50}=1.94 \mathrm{mg} / \mathrm{mL}\right), S$. corymbosum $\left(\mathrm{IC}_{50}=2.47 \mathrm{mg} / \mathrm{mL}\right), S$. gummiferum subsp. gummiferum $\left(\mathrm{IC}_{50}=3.07 \mathrm{mg} / \mathrm{mL}\right)$, and S. campestre $\left(\mathrm{IC}_{50}=4.27 \mathrm{mg} / \mathrm{mL}\right)$ extracts.

The $\mathrm{MeOH}$ extracts of Seseli species have a higher DPPH radical scavenging effect than AcOEt extracts. The results showed that $\mathrm{MeOH}$ extracts of $S$. resinosum, S. gummifeum subsp. gummiferum, and $S$. peucedanoides have the highest scavenging capacity $\left(\mathrm{IC}_{50}=0.086\right.$, $I C_{50}=0.088$, and $I C_{50}=0.091$, respectively).

The TBA test results showed that $\mathrm{MeOH}$ extracts of Seseli spp. exhibited potent antioxidant effects $(81-96 \%$ inhibition at 5 and 10 $\mathrm{mg} / \mathrm{mL}$ concentrations) when compared to $\alpha$-tocopherol. The AcOEt and $\mathrm{MeOH}$ extracts of $S$. tortuosum have the strongest anti-LPO activity (84-96\% inhibition at a dose of $10 \mathrm{mg}$ ). The AcOEt and $\mathrm{MeOH}$ extracts of $S$. campestre, S. andronakii, and S. gummiferum subsp. gummiferum also exhibited a high anti-LPOeffect in the LPO assay (Table 4).

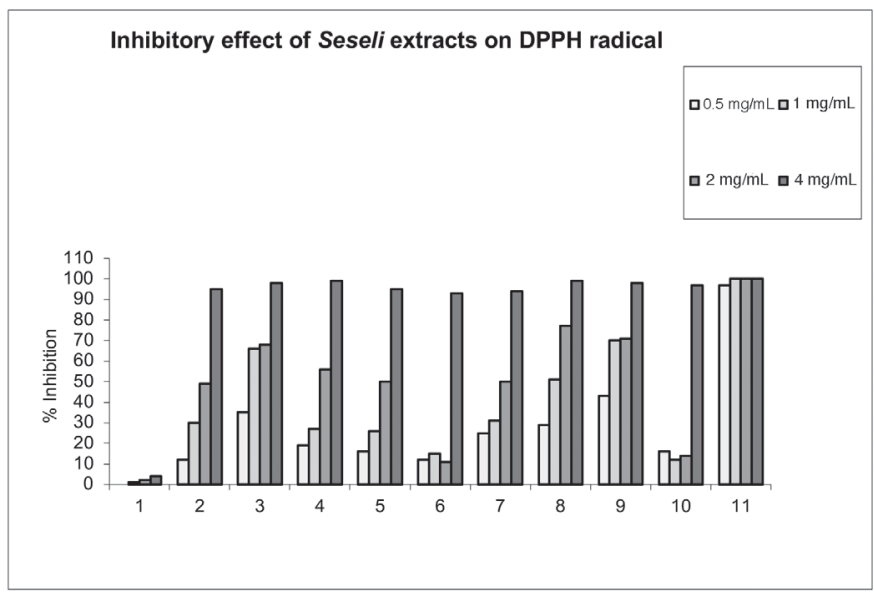

Figure 1. Ethyl acetate extracts of Seseli species (1-10) and (11) $\alpha$-tocopherol at various concentrations

(1) S. andronakii, (2) S. hartvigii, (3) S. tortuosum, (4) S. libanotis,

(5) S. gummiferum subsp. gummiferum, (6) S. peucedanoides, (7) S. resinosum, (8) S. corymbosum, (9) S. campestre, (10) S. petraeum

\begin{tabular}{|c|c|c|c|c|c|c|}
\hline & Concentrations $\mathrm{mg} / \mathrm{mL}$ & nmol MDA/g tissue & $\%$ Inhibition & Concentrations $\mathrm{mg} / \mathrm{mL}$ & nmol MDA/g tissue & $\%$ Inhibition \\
\hline Control & \multicolumn{3}{|c|}{ AcOEt extracts } & \multicolumn{3}{|c|}{$\mathrm{MeOH}$ extracts } \\
\hline$b$ & & & $\mathrm{NE}^{\mathrm{c}}$ & & & $\mathrm{NE}^{\mathrm{c}}$ \\
\hline \multirow[t]{2}{*}{ SA } & 2.5 & 0.148 & 34 & 5 & 0.027 & 88 \\
\hline & 5 & 0.045 & 80 & 10 & 0.024 & 89 \\
\hline \multirow[t]{2}{*}{$\mathrm{SH}$} & 2.5 & 0.084 & 63 & 5 & 0.026 & 88 \\
\hline & 5 & 0.052 & 77 & 10 & 0.025 & 89 \\
\hline \multirow[t]{2}{*}{ ST } & 2.5 & 0.102 & 55 & 5 & 0.011 & 95 \\
\hline & 5 & 0.036 & 84 & 10 & 0.009 & 96 \\
\hline \multirow[t]{2}{*}{ SL } & 2.5 & 0.222 & 1.2 & 5 & 0.037 & 83 \\
\hline & 5 & 0.085 & 45 & 10 & 0.014 & 94 \\
\hline \multirow[t]{2}{*}{ SGG } & 2.5 & 0.085 & 62 & 5 & 0.042 & 81 \\
\hline & 5 & 0.039 & 82 & 10 & 0.035 & 84 \\
\hline \multirow[t]{2}{*}{ SPeu } & 2.5 & 0.195 & 13 & 5 & 0.021 & 91 \\
\hline & 5 & 0.129 & 43 & 10 & 0.022 & 90 \\
\hline \multirow[t]{2}{*}{ SR } & 2.5 & 0.144 & 36 & 5 & 0.043 & 81 \\
\hline & 5 & 0.049 & 78 & 10 & 0.026 & 88 \\
\hline \multirow[t]{2}{*}{ SC } & 2.5 & 0.151 & 33 & 5 & 0.025 & 89 \\
\hline & 5 & 0.067 & 70 & 10 & 0.018 & 92 \\
\hline \multirow[t]{2}{*}{$\mathrm{SCa}$} & 2.5 & 0.088 & 61 & 5 & 0.025 & 89 \\
\hline & 5 & 0.043 & 81 & 10 & 0.02 & 91 \\
\hline \multirow[t]{2}{*}{ SP } & 2.5 & 0.156 & 31 & 5 & 0.028 & 87 \\
\hline & 5 & 0.058 & 74 & 10 & 0.026 & 81 \\
\hline \multirow[t]{2}{*}{$\alpha$-Tocopherol } & 0.22 & 0.009 & 96 & 0.22 & 0.009 & 96 \\
\hline & 0.44 & 0.003 & 99 & 0.44 & 0.003 & 99 \\
\hline
\end{tabular}

${ }^{a}$ Each value represents the mean \pm standard deviation of 2-4 independent experiments, ${ }^{b} \mathrm{AcOEt}$ or MeOH only, control for extracts, ${ }^{\mathrm{c} N E}$ : No effect

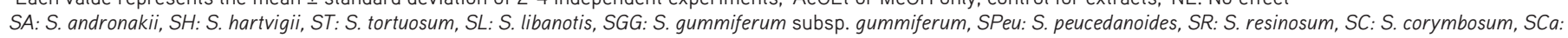

S. campestre, SP: S. petraeum 
In previous studies, the antioxidant potency of $\mathrm{MeOH}$ extract of S. pallasii, S. libanotis subsp. libanotis, and $S$. libanotis subsp. intermedium (aerial parts and fruits) was determined. S. libanotis subsp. libanotis showed the strongest antioxidant activity in the DPPH assay. ${ }^{54}$ Various extracts in different polarities from the roots, leaves, flowers, and fruit of $S$. rigidum were also studied, and the hexane extract of the root had the best effect among the other plant parts in the DPPH assay. ${ }^{55,56}$ In another study, the antioxidant activity of Seseli rigidum was evaluated in five extracts in different polarities (water, $\mathrm{MeOH}$, acetone, ethyl acetate, and petroleum ether). The antioxidant effect of the aerial parts of the species was determined in vitro using DPPH reagent, and the highest antioxidant activity was expressed in water extract $(46.15 \mu \mathrm{g} / \mathrm{mL}) .{ }^{57}$ Moreover, some of the compounds isolated from the methanolic extracts (80\%) of Seseli diffusum have been found to have a strong antioxidant effect. 58

It is known that Seseli species contain phenolic compounds consisting mainly of coumarins, ${ }^{16}$ which have notable antioxidant potency. ${ }^{59-61}$ In addition, mostly oxygenated coumarins are accumulated in the AcOEt fractions, and the glycosides are present in the $\mathrm{MeOH}$ extract. The $\mathrm{MeOH}$ extract exhibits higher antioxidant activity, which may be explained by the presence of coumarin glucosides as highly polar compounds in the extract. The results show that there seemed to be a good match between the content of the extracts and the antioxidant capacity. Finally, the activity might be due to the polar coumarins of the active Seseli species. . $^{52} 62$

\section{CONCLUSION}

Natural products are generally known to be a good source of active compounds that have potential for the development of new therapeutic agents. The antioxidant properties of the AcOEt and $\mathrm{MeOH}$ extracts of Seseli species expressed as $\alpha$-tocopherol equivalent antioxidant capacity were studied using DPPH and LPO assays. These results indicate that plant extracts prevent oxidative damage in normal cells due to their antioxidant properties. The best part of our research was that Seseli species growing in Turkey were screened for the first time for their antioxidant capacity. In addition, this research provides a scientific basis for the medicinal use of these plant materials. Therefore, we can conclude from the results of the present study that Seseli species may be a potential source of natural antioxidant compounds for the treatment of oxidative degeneration.

Conflicts of interest: No conflict of interest was declared by the authors.

\section{REFERENCES}

1. Sayed-Ahmad B, Talou T, Saad Z, Hijazi A, Merah O. The Apiaceae: ethnomedicinal family as a source for industrial uses. Ind Crops Prod. 2017;109:661-671.

2. Crowden RK, Harborne JB, Heywood VH. Chemosystematics of the Umbelliferae - a general survey. Phytochemistry. 1969;8:1963-1984.
3. Lawrence GHM. Taxonomy of Vascular Plants. New York; Macmillan; 1969:642-646.

4. Pimenov MG, Leonov MV. The Genera of the Umbelliferae. London; Royal Botanic Gardens; 1993.

5. Hedge IC, Lamond JM. Seseli L. In Davis PH, ed. Flora of Turkey and the East Aegean Islands, vol. 4. Edinburgh; Edinburgh University Press; 1972.

6. Davis PH, Mill RR, Tan K. Flora of Turkey and the East Aegean Islands, vol. 10. Edinburgh; Edinburgh University Press; 1988.

7. Duman H. Seseli L. In Güner A, Özhatay N, Ekim T, Başer KHC, eds. Flora of Turkey and the East Aegean Islands, vol. 11. Edinburgh; Edinburgh University Press; 2000.

8. Parolly G, Nordt B. Seseli hartvigii (Apiaceae), a new name for $S$. ramosissimum Hartvig \& Strid, with carpological and ecological notes on this species. Willdonowia. 2001;31:87-93.

9. Pimenov MG, Kljuykov EV. Inclusion of eriocycla into Seseli (Umbelliferae) and description of some new sections and subsections within the genus Seseli. Bot Zhurn. 2000;85:96-109.

10. Pimenov MG, Kljuykov EV. Two new species of Seseli (Umbelliferae) from Turkey. Fl Medit. 2010;20:19-27.

11. Güner $E$, Duman $H$. The revision of genus Seseli (Umbelliferae) in Turkey. Turk J Bot. 2013;37:1018-1037.

12. Çetin Ö, Şeker MÖ, Duran A. A new subspecies of Seseli gummiferum (Apiaceae) from the Ilgaz Mountain National Park, Northern Turkey. Phyto Keys. 2015;56:99-110.

13. Lyskov D, Doğan Güner E, Samigullin T, Duman H, Pimenov M. Molecular data to elucidate the taxonomy of Seseli sect. Seseli (Apiaceae) in east Mediterranean and southern Europe. Nordic J Bot. 2018;2018:e01857.

14. Hamlyn P. The Marshall Cavendish Encyclopedia of Gardening. vol. 19. London; Garrod and Lofthouse International; 1969.

15. Barrero AF, Herrador MM, Arteaga P. Cumarinas en especies del genero Seseli. (Fam. Umbelliferae). Ars Pharm. 1990;31:241-256.

16. Tosun A, Özkal N. Seseli L. (Umbelliferae) türlerinin kimyasal bileșimi ve biyolojik aktiviteleri/Chemical constituents and biological activities of Seseli L. (Umbelliferae) species. J Fac Pharm Ankara. 2003;32:269-284.

17. Hu CQ, Chang JJ, Lee KH. Antitumor agents, 115. Seselidiol, a new cytotoxic polyacetylene from Seseli mairei. J Nat Prod 1990;53:932-935.

18. Tandan SK, Chandra S, Tripathi HC, Lal J. Pharmacological actions of seselin, a coumarin from Seseli indicum seeds. Fitoterapia. 1990;61:360363.

19. Austin PW, Seshadri TR, Sood MS, Vishwapaul. Components of Seseli sibiricum: constitution and synthesis of sibiricin, a new coumarin. Tetrahedron. 1968;24:3247-3253.

20. Syed M, Chaudhary FM, Bhatty MK. Antimicrobial activity of the essential oils of the Umbelliferae family. Part VIII. Seseli libanotis, Ligusticum stewartii, and Pycnocycla aucheriana oils. Pak J Sci Ind Res. 1989;32:316-319.

21. Dixit V, Chaturvedi RV, Tripathi SC. Evaluation of some essential oils against Pulse Bettle (Callosobruchus chinensis). Natl Acad Sci Lett. 1992;15:255-257.

22. Chaturvedi RV, Tripathi SC. Fungutoxic, physicochemical and phytotoxic properties of essential oil of Seseli indicum W and A. J Phytopathol. 1989;124:316-322.

23. Baytop T. Türkiye'de Bitkilerle Tedavi. Therapy with Plants in Turkey (Past and Present) (2nd ed). İstanbul; Nobel Medical House; 1999. 
24. Baytop T. Türkçe Bitki Adları Sözlüğü, Atatürk Kültür, Dil ve Tarih Yüksek Kurumu, TDKY 3578, Ankara; TTK Basımevi; 1994.

25. Tosun A, Özkal N, Baba M, Okuyama T. Pyranocoumarins from Seseli gummiferum subsp. corymbosum growing in Turkey. Turk J Chem. 2005;29:327-334.

26. Tosun A. Occurrence of coumarins in Seseli hartvigii growing in Turkey. Chem Nat Compd. 2006;42:608-609.

27. Tosun A, Baba M, Bahadır Ö, Okuyama T. Coumarins isolated from the roots of Seseli resinosum in Turkey. Pharm Biol. 2006;44:528-533.

28. Zhang L, Tosun A, Baba M, Okada Y, Wu L, Okuyama T. Coumarins from Seseli hartvigii. Nat Prod Commun. 2010;5:1067-1070.

29. Shehzad O, Khan S, Ha IJ, Park Y, Tosun A, Kim YS. Application of stepwise gradients in counter-current chromatography: a rapid and economic strategy for the one-step separation of eight coumarins from Seseli resinosum. J Chromatogr A. 2013;1310:66-73.

30. Başer KHC, Özek T, Kürkçüoglu M, Aytaç Z. Essential oil of Seseli campestre Besser. J Essent Oil Res. 2000;12:105-107.

31. Kaya A, Demirci B, Baser KHC. The essential oil of Seseli tortuosum growing in Turkey. Flavour Fragrance J. 2003;18:159-161.

32. Tosun A, Baba M, Kodama T, Nakanishi H, Okuyama T. The composition of essential oils of Seseli species growing in Turkey. Nat Med 2005;59:85-90.

33. Tosun A, Doğan E, Duman H, Kürkçüoğlu M, Bașer KHC. Essential oil composition of the fruits of Seseli resinosum Freyn et Sint. and Seseli tortuosum L. growing in Turkey. J Essent Oil Res. 2006;18:57-59.

34. Tosun A, Kürkçüoğlu M, Doğan E, Duman H, Başer KHC. Essential oil composition of Seseli petraeum M. Bieb. and Seseli andronakii Woron. growing in Turkey. Flavour Fragrance J. 2006;21:257-259.

35. Tosun A, Özkal N, Yıldız S. Antimicrobial activity screening of some Seseli L. species growing in Turkey. Ankara Ecz Fak Derg. 2004;33:151155.

36. Küpeli E, Tosun A, Yeșilada E. Anti-inflammatory and antinociceptive activities of Seseli L. species (Umbelliferae) growing in Turkey. J Ethnopharmacol. 2006;104:310-314.

37. Tosun A, Akkol EK, Yeșilada E. Anti-inflammatory and antinociceptive activities of Seseli L. species (Apiaceae) growing in Turkey. Z Natur Forsch C. 2009;64:56-62.

38. Chun J, Tosun A, Kim YS. Anti-inflammatory effect of corymbocoumarin from Seseli gummiferum subsp. corymbosum through suppression of NF-KB signaling pathway and induction of HO-1 expression in LPSstimulated RAW 264.7 cells. Inter Immunopharmacol. 2016;31:207-215.

39. Lee SE, Hwang HJ, Ha J-S, Jeong H-S, Kim JH. Screening medicinal plant extracts for antioxidant activity. Life Sci. 2003;73:167-179.

40. Kim M-B, Park J-S, Lim S-B. Antioxidant activity and cell toxicity of pressurized liquid extracts from 20 selected plant species in Jeju, Korea. Food Chem. 2010;122:546-552.

41. Shahidi F, Yeo J. Bioactivities of phenolics by focusing on suppression of chronic diseases: a review. Int J Mol Sci. 2018;25:19:1573.

42. Olas B. Berry phenolic antioxidants - implications for human health? Front Pharmacol. 2018;9:78.

43. $\mathrm{Ng} \mathrm{TB}$, Liu F, Wang ZT. Antioxidative activity of natural products from plants. Life Sci. 2000;66:709-723.

44. Krishnaiah D, Sarbatly R, Nithyanandam R. A review of the antioxidant potential of medicinal plant species. Food Bioprod Process. 2011;89:217-233.
45. Muraina IA, Suliman MM, Eloff JN. Can MTT be used to quantify the antioxidant activity of plant extracts? Phytomedicine. 2009;16:665-668.

46. Halliwell B, Gutteridge JMC. Free Radicals in Biology and Medicine. Oxford; Clarendon Press; 1989.

47. Wong SP, Leong LP, Koh JHW. Antioxidant activities of aqueous extracts of selected plants. Food Chem. 2006;9:775-783.

48. Fenglin $\mathrm{H}$, Ruili L, Bao $\mathrm{H}$, Liang $M$. Free radical scavenging activity of extracts prepared from fresh leaves of selected Chinese medicinal plants. Fitoterapia. 2004;75:14-23.

49. Báthori M, Zupkó I, Hunyadi A, Gácsné-Baitz E, Dinya Z, Forgó P. Monitoring the antioxidant activity of extracts originated from various Serratula species and isolation of flavonoids from Serratula coronata. Fitoterapia. 2004;75:162-167.

50. Blois MS. Antioxidant determination by the use of a stable free radical. Nature. 1958;181:1199-1200.

51. Mihara M, Uchiyama M, Fukuzawa K. Thiobarbituric acid value on fresh homogenate of rat as a parameter of lipid peroxidation in aging, $\mathrm{CCl}_{4}$ intoxication, and vitamin E deficiency. Biochem Med. 1980;23:302-311.

52. Liu F, Ng TB. Antioxidative and free radical scavenging activities of selected medicinal herbs. Life Sci. 2000;66:725-735.

53. Ellnain-Wojtaszek M, Kruczynski Z, Kasprzak J. Investigation of the free radical scavenging activity of Ginkgo biloba L. leaves. Fitoterapia. 2003;74:1-6.

54. Matejić JS, Džamić AM, Mihajilov-Krstev T, Ranđelović VN, Krivošej ZD, Marin PD. Total phenolic content, flavonoid concentration, the antioxidant and antimicrobial activity of methanol extracts from three Seseli L. taxa. Cent Eur J Biol. 2012;7:1116-1122.

55. Stojkovic S, Petrovic S, Kukic J, Dzamic A, Ristic M, Milenkovic M, Glamoclija J, Sokovic M, Stojkovic D. Chemical composition and antimicrobial and antioxidant activity of Seseli rigidum flower essential oil. Chem Nat Compd. 2009;45:253-256.

56. Stankov-Jovanović VP, Ilić MD, Mitić VD, Mihajilov-Krstev TM, Simonović SR, Nikolić Mandić SD, Tabet JC, Cole RB. Secondary metabolites of Seseli rigidum: chemical composition plus antioxidant, antimicrobial and cholinesterase inhibition activity. J Pharm Biomed Anal. 2015;111:78-90.

57. Jakovljević D, Vasić S, Stanković M, Čomić L, Topuzović M. In vitro biological activity of secondary metabolites from Seseli rigidum Waldst. et Kit. (Apiaceae). Acta Biol Hung. 2015;66:395-405.

58. Abbaskhan A, Choudhary MI, Ghayur MN, Parween Z, Shaheen F, Gilani AU, Maruyama T, Iqbal K, Tsuda Y. Biological activities of Indian celery, Seseli diffusum (Roxb. ex Sm.) Sant. \& Wagh. Phytother Res. 2012;26:783-786.

59. Torres FC, Brucker N, Andrade SF, Kawano DF, Garcia SC, Poser GL, Eifler-Lima VL. New insights into the chemistry and antioxidant activity of coumarins. Curr Top Med Chem. 2014;14:2600-2623.

60. Pereira TM, Franco DP, Vitorio F, Kummerle AE. Coumarin compounds in medicinal chemistry: some important examples from the last years. Curr Top Med Chem. 2018;18:124-148.

61. Zhu JJ, Jiang JG. Pharmacological and nutritional effects of natural coumarins and their structure-activity relationships. Mol Nutr Food Res. 2018;11:e1701073.

62. O'Kennedy R, Thornes RD. Coumarins: Biology, Applications and Mode of Action. Chichester; John Wiley \& Sons; 1997. 